\title{
Cartoon Vision
}

\section{UPA ANIMATION AND POSTWAR AESTHETICS}

\author{
Dan Bashara
}

\section{प}


University of California Press, one of the most distinguished university presses in the United States, enriches lives around the world by advancing scholarship in the humanities, social sciences, and natural sciences. Its activities are supported by the UC Press Foundation and by philanthropic contributions from individuals and institutions. For more information, visit www.ucpress.edu.

University of California Press

Oakland, California

(C) 2019 by Dan Bashara

Library of Congress Cataloging-in-Publication Data

Names: Bashara, Daniel, 1982- author.

Title: Cartoon vision : UPA animation and postwar aesthetics / Daniel Bashara.

Description: Oakland, California : University of California Press, [2019] | Includes bibliographical references and index. |

Identifiers: LCCN 2018038418 (print) | LCCN 2018042106 (ebook) | ISBN 9780520970380 (Epub) | ISBN 9780520298132 (cloth : alk. paper) | ISBN 9780520298149 (pbk. : alk. paper)

Subjects: LCSH: Animated films-United States-History and criticism. | United Productions of America. | Animated films-Aesthetics. | Art and motion pictures. | Motion pictures and architecture.

Classification: LCC NCi766.U5 (ebook) | LCC NCi766.U5 B38 2019 (print) | DDC 791.43/340973-dc23

LC record available at https://lccn.loc.gov/2018038418

$\begin{array}{llllllllll}28 & 27 & 26 & 25 & 24 & 23 & 22 & 21 & 20 & 19\end{array}$

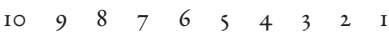


Cartoon Vision 
The publisher and the University of California Press Foundation gratefully acknowledge the generous support of the Abmanson Foundation Endowment Fund in Humanities. 
To my parents, Chris and Sue Bashara, who made everything possible 
